\title{
A Joint Commission International-Accredited Small-scale Clinic: A Case Report
}

\author{
Yeon-Soo Hwang ${ }^{1}$, Hae Won Lee ${ }^{2}$, Eun Hee Kim³ ${ }^{3}$ Pok-kee Min ${ }^{4}$ \\ 'Student, College of Nursing, Kyungpook National University, Daegu; ${ }^{2}$ Clinical Professor, Department of Clinical Pharmacology and Clinical Trial Center, \\ Kyungpook National University Hospital, Daegu; ${ }^{3}$ Professor, College of Nursing, Daegu Catholic University, Daegu; ${ }^{4}$ Chief Director, AllforSkin Dermatology \\ Clinic, Daegu, Korea
}

Objectives: The increased focus on patient safety and quality of health care has continually led hospital accreditation to grow internationally. Joint Commission International $(\mathrm{JCl})$ accreditation is the most representative entity in the international context. The extensive parameters used in $\mathrm{JCl}$ accreditation standards make bigger facilities have a greater advantage in practical terms. However, it is possible to establish the JCl framework into a more suitable form for the capacity of smaller medical facilities. This case report aimed to summarize its relevant experiences in a small-scale clinic whilst working on the accreditation, and to discuss the lessons from such interventions in outpatient care during the period of before and after JCl accreditation. Methods: This study with a three-year follow up was conducted in a small-scale local clinic in which JCl accreditation was successfully passed in 2016 . Data was collected by conducting interviews with the staff in charge of handling $\mathrm{JCl}$ accreditation, and the relevant experiences focusing on international patient safety goals and medication management were summarized, with the lessons from such interventions in outpatient care during the period of before and after JCl accreditation. Results: Participating in the accreditation process and the three-year follow-up analysis revealed that the initial low levels of compliance with standards to improve patient safety and quality of healthcare in this clinic have been much improved. Conclusions: Based on finding of the case report, $\mathrm{JCl}$ accreditation in small-scale clinic may enhance its awareness and capacity to achieve successful quality improvement.

Key words: JCl, Small-scale clinic, Accreditation, Quality improvement, Medication management

The increased focus on improving patient safety and quality of health care in the international community has led to the need for the standardized evaluation processes of health care organizations, including accreditation [1,2]. Founded in 1994 by The Joint Commission, Joint Commission International (JCI) headquartered in USA is one of the well-established international accreditation bodies of health care organizations over 90 countries outside of the United States [3-5]. From academic medical centers and hospitals to primary care providers, there are hundreds of JCI-accredited health care organizations all over the world [6]. The standards for JCI accreditation to focus on patient safety and quality of health care in the international community are categorized according to the accreditation programs applied by the health care organizations, including academic medical center hospitals, ambulatory care, laborato-

Corresponding author: Eun Hee Kim

33 Duryugongwon-ro 17-gil, Nam-gu, Daegu 42472, Korea

E-mail: ag0115@cu.ac.kr

Received: March 11, 2021 Revised: April 2, 2021 Accepted: April 6, 2021

No potential conflict of interest relevant to this article was reported. ry, home care, long term care, medical transport organizations, and primary care centers [6].

According to JCI Accreditation Standards for Hospitals and JCI Accreditation Standards for Ambulatory Care, the standards are divided into two principal sections: patient-centered care and health care organization management $[7,8]$. Several standards with the rationale of the standard and the specific requirements of the standard are included in each section: international patient safety goals (IPSG), access to care and continuity of care, patient and family rights, assessment of patients, care of patients, anesthesia and surgical care, medication management and use (MMU), and patient and family education for patient-centered standards; quality improvement and patient safety, prevention and control of infections, governance, leadership, and direction, facility management

How to cite this article:

Hwang YS, Lee HW, Kim EH, Min PK. A Joint Commission International (JCI)-accredited small-scale clinic: a case report. J Health Info Stat 2021;46(2):141-146. Doi: https://doi.org/10.21032/jhis.2021.46.2.141

(c) It is identical to the Creative Commons Attribution Non-Commercial License (https://creativecommons.org/licenses/by-nc/4.0) which permit sunrestricted non-commercial use, distribution, and reproduction in any medium, provided the original work is properly cited.

(c) 2021 Journal of Health Informatics and Statistics 
Table 1. Eleven health care organizations accredited by Joint Commission International in Republic of Korea, based on a 2021 statistics

\begin{tabular}{lc}
\hline Variables & Number of organizations \\
\hline City & \\
Seoul & 4 \\
Suwon & 2 \\
Daegu & 2 \\
Busan & 3 \\
Program & \\
Hospital program & 1 \\
Ambulatory care program & 6 \\
Academic medical center hospital program & 4 \\
\hline
\end{tabular}

and safety, staff qualifications and education, and management of information for health care organization management standards.

In fact, one of the reasons why big hospitals are more likely to be the candidates for JCI accreditation is because the extensive parameters used in JCI accreditation standards make bigger facilities have a greater advantage in practical terms. However, since the purpose of the accreditation is to improve patient safety and quality of health care, it is possible to forge the JCI framework into a more suitable form for the capacity of smaller medical facilities. Among 11 JCI-accredited health care organizations located in Republic of Korea as of March 2021 (Table 1), AllforSkin Dermatology Clinic, Hair \& Laser Center, Daegu, Republic of Korea, serves as an example of a small-scaled clinic accredited by JCI ambulatory care program [9]. This dermatology clinic became the first JCIaccredited organization in Daegu, and the third in Asia as a dermatology clinic on September 24, 2016. An average of ten thousand outpatients are treated annually in this ambulatory care organization, with an average of thirty outpatient beds for dermatology procedures and ten treatment chairs to the Hair and Scalp center Procedures (Table 2). Many of the clinic's leading treatments require laser devices, which the clinic provides with the noble Picosecond machine. Furthermore, some of the procedures in high demand for this clinic, such as Botox and hair transplants, would entail greater risk of infections (Table 3). Thus, it was evident that implementing the JCI guidelines would benefit the clinic due to the higher standards of record keeping that are expected under such schemes. Accordingly, the study with a three-year follow up was conducted in this local clinic.

This study with a three-year follow up was conducted in a small-scale local clinic in which JCI accreditation was successfully passed in 2016. Data was collected by conducting interviews with the staff in charge of
Table 2. Description of the area calculation, spatial composition, personnel and outpatients at AllforSkin Dermatology Clinic, Hair \& Laser Center

\begin{tabular}{lr}
\hline Dimension $\left(\mathrm{m}^{2}\right)$ & 750 \\
\hline No. of beds for skincare in dermatology $(\mathrm{n})$ & 17 \\
No. of beds for laser and treatment room $(\mathrm{n})$ & 13 \\
No. of chairs for hair and scalp therapy center $(\mathrm{n})$ & 10 \\
No. of personnel $(\mathrm{n})$ & 20 \\
Average No. of outpatients per year $(\mathrm{n})$ & 10,000 \\
\hline
\end{tabular}

Table 3. Top five procedures and diagnoses at AllforSkin Dermatology Clinic

\begin{tabular}{ll}
\hline Top five procedures & Top five diagnoses \\
\hline $\mathrm{CO}_{2}$ Laser & Seborrheic dermatitis \\
Laser toning & Alopecia areata \\
Botox & Male pattern hair loss \\
Excimer laser & Vitiligo \\
Hair Transplantation & Atopic dermatitis \\
\hline
\end{tabular}

handling JCI accreditation, and the relevant experiences focusing on international patient safety goals and medication management were summarized, with the lessons from such interventions in outpatient care during the period of before and after JCI accreditation.

Although JCI advocates improvements in patient safety and healthcare quality through accreditation, there has been limited literature on the experiences in the effectiveness of accreditation. This case report aimed to summarize its relevant experiences whilst working on the accreditation, focusing on IPSG and MMU, the standards for patient-centered care mentioned above, and to discuss the lessons from such interventions in outpatient care during the period of before and after JCI accreditation. The processes implemented to improve patient safety and quality of healthcare are summarized in Table 4.

\section{Measures for international patient safety goals}

The main measures to promote specific improvements in patient safety are as follows:

1. Identifying patients correctly. To improve accuracy of patient identification in this clinic, a meeting to report the daily scheduled appointments is held in the morning every day, and documented for more accurate understanding and preparation. A policy that the patient must be identified using his full name and the date of birth, and should be double checked at every contact point was established and implemented.

2. Improving effective communication. To help patients and staff 
Table 4. The processes implemented to improve patient safety and quality of healthcare in target areas of emphasis during the Joint Commission International accreditation process

\begin{tabular}{|c|c|c|}
\hline Section & Standards & The process implemented to improve \\
\hline IPSG 1 & Identify patients correctly & $\begin{array}{l}\text { A daily meeting to report the daily appointments, and patient identification } \\
\text { double checked at every contact point }\end{array}$ \\
\hline IPSG 2 & Improve effective communication & Frequent use of questionnaires, and no use of jargon \\
\hline IPSG 3 & Improve the safety of high-alert medications & $\begin{array}{l}\text { All high-alert medications highlighted on the list, labeled properly, and kept } \\
\text { in a controlled storage area }\end{array}$ \\
\hline IPSG 4 & Ensure correct-site, correct-procedure, correct-patient surgery & $\begin{array}{l}\text { Time-out monitoring process for each patient for collective date used for } \\
\text { ensuring patient safety }\end{array}$ \\
\hline IPSG 6 & Reduce the risk of patient harm resulting from falls & $\begin{array}{l}\text { Initial and ongoing assessment, reassessment, and intervention of patients' } \\
\text { risk for falls }\end{array}$ \\
\hline MMU 3 & Mediation management and use; storage & $\begin{array}{l}\text { Training for proper and safe storage of medications and emergency } \\
\text { medications and equipment }\end{array}$ \\
\hline SQE & Staff qualifications and education & $\begin{array}{l}\text { Using a standardized process to evaluate the quality and safety of patient } \\
\text { care by each staff member }\end{array}$ \\
\hline
\end{tabular}

IPSG, international patient safety goals; MMU, medication management and use; SQE, staff qualifications and education; $\mathrm{PCl}$, prevention and control of nfections.

members become more informed about their care plans, the facility must employ a robust system of protocol, record and administration protections. This is of critical importance in providing all patients with clear information of care plans and must be presented in a way that they can easily comprehend and retain throughout their procedures. Use of jargon must be ceased. For gathering patient feedbacks, frequent use of questionnaires is highly recommended as this can have a huge impact on the consistency of communication between patients and staff members Regulations on terminology and communications need to be effectively informed during the morning staff consultation and provide explicit notification of any alterations.

3. Improving the safety of high-alert medications. The main interventions to improve the safety of high-alert medications (medications that have the highest risk of causing injury when misused) in this clinic were as follows:

a. Improving access to information about high-alert medications. All high-alert medications must be highlighted on the list of medications.

b. Limiting access to these medications. Each medication must be kept in a controlled storage area, locked in the safe according to a rule of 'double person double lock' (ie, a safe has two locks and two keys. Two different persons keep each key, and the medica- tion can be taken out of the safe only when these two persons are available at the site).

c. Labeling properly. All high-alert medication containers, product packages and loose vials stored must be labeled as 'HIGH ALERT MEDICATION'.

d. Separating drugs with a similar name or appearance. Each sound-alike and look-alike drug or different strength of the same drug must be differentiated by a differently colored sticker, without being stored side by side. Each staff should ensure that these medications are kept at the correct place.

e. Standardizing the ordering, storage, preparation, and administration of these medications.

f. Checking the quantity of high-alert medications in stock every day.

\section{Measures on medication management and use}

The main intervention measures on the management and use of medications in this clinic are as follows:

1. Developing and following the standardized processes of medication administration to ensure patient safety. Before determining the standardized processes of medication administration, a more thorough analysis of the points of contact related to the potential for medication administration errors between patients and medical 
personnel was performed. The standardized processes to prevent medication administration errors and to report the errors occurred were documented and posted at every potential contact point to be recognized by all the personnel, including the issuing of prescription, dispensing, packaging and labeling of medications, and administration of medications.

2. Identifying and reporting the medication administration errors and adverse events promptly, using a standardized format for reporting.

3. Medication safety monitoring is held monthly by each personnel who are responsible for high-alert medications and post dosing.

4. Categorizing medication administration errors. Seven categories of medication administration errors from level 0 to level 6 were proposed according to the severity of the errors, by using the National Coordinating Council for Medication Error Reporting and Prevention Index for Categorizing Medication Errors [10]. Levels of medication errors developed were as follows: Level $0=$ Circumstances or events that have the capacity to cause error, or errors occurred but the error did not reach the patient; Level $1=$ Errors occurred that reached the patient but did not cause patient harm; Level 2 =Errors occurred that reached the patient, with increased need for required monitoring to confirm that it resulted in no harm to the patient and/or required intervention to preclude harm, and no change of vital signs; Level 3 =Errors occurred that may have contributed to or resulted in temporary harm to the patient, with increased need for required monitoring due to change of vital signs; Level $4=$ Errors occurred that may have contributed to or resulted in temporary harm to the patient and required intervention with another medication, or transfer to another hospital; Level $5=$ Errors occurred that may have contributed to or resulted in permanent harm to the patient; Level $6=$ Errors occurred that may have contributed to or resulted in patient's death.

5. Maintaining the optimal temperature of medication storage sites. To provide good quality medications, the expiration date of medications and the temperature of storage sites are monitored and documented daily.

\section{After achieving $\mathrm{JCl}$ accreditation}

As of March 2021, the clinic achieved the second JCI accreditation in 2019. As the JCI standards for accreditation followed revised measures, a few changes became more scrupulous to accommodate. Since infection control of MMU and IPSG imposes universal standards, implementation of specific environmental quality controls and designing or referencing specific assessment tools to comply with the standards faced challenges during the second accreditation process. Although the clinic was accredited by JCI, some criteria either received 'Partially met' or 'Not met'. First, the second accreditation required a more intensive inspection of MMU standards. The clinic, in some aspects, had received 'Not met' for "Prevention and Control of Infections (PCI)" due to the temperature-unfavorable position of autoclaves, among other appliances. This can be improved upon next accreditation by repositioning the autoclaves to operation rooms where humidity and temperature are most regularly inspected. Second, the revised accreditation "Patient and Family Education (PFE.2.1)” was 'Partially met.' Although the clinic assessed the patient's language, they did not assess the health care literacy and educational level. The clinic may meet the criteria if they advise educational resources in different languages for foreign patients. Besides, PFE.2.1 required assessing patients' emotional barriers and motivations, which the clinic had 'Not met.' The clinic may research comparative literature to effectuate corresponding assessments and meet the standard upon the next accreditation. Third, the clinic partially met the standard "Reduce the Risk of Patient Harm Resulting from Falls Policy" (IPSG) as they failed to reassess patients before discharge after clinical procedures. The clinic may design a checklist tailored to this assessment and persist regular monitoring and identification of at-risk for falls. Lastly, they received 'Partially met' for "Staff Qualifications and Education (SQE.9)" because the monitoring and evaluation of staff qualifications lacked comparison to other department medical staff members. With a solid foundation of quality and safety identification, they may reduce the evaluating subjects by limiting staff quality evaluation within the same occupations.

The clinic's consistent acclimation of the JCI accreditation played a significant role in providing protective measures especially during the global pandemic. IPSG and MMU especially enabled the center to deviate from any COVID-19 contacts amidst the peak severity of the COVID-19 outbreak of March 2019. In addition to IPSG, the clinic had installed one-way-circulation modes for heating, ventilation, and air-conditioning (HVAC) systems, which served as an impetus to reduce transmission of airborne disease during a pandemic.

Participating in the accreditation process and the three-year follow-up analysis reveals that the initial low levels of compliance with standards to 
improve patient safety and quality of healthcare in this clinic have been much improved. The continuous multidisciplinary collaboration among physicians, pharmacists, nurses, and hospital administrators is important in improving patient safety and quality of healthcare. JCI accreditation may enhance the awareness and capacity of health care organizations to achieve successful quality improvement.

\section{REFERENCES}

1. Viswanathan HN, Salmon JW. Accrediting organizations and quality improvement. Am J Manag Care 2000;6(10):1117-1130.

2. Brubakk K, Vist GE, Bukholm G, Barach P, Tjomsland O. A systematic review of hospital accreditation: the challenges of measuring complex intervention effects. BMC Health Serv Res 2015;15:280. DOI: 10.1186/ s12913-015-0933-X

3. Joint Commission International. Who is JCI. Available at http://www. jointcommissioninternational.org/about-jci/who-is-jci [accessed on March 03, 2021].

4. Shaw CD, Braithwaite J, Moldovan M, Nicklin W, Grgic I, Fortune T, et al. Profiling health-care accreditation organizations: an international survey. Int J Qual Health Care 2013;25(3):222-231. DOI: 10.1093/intqhe/mzt011
5. Oliveira JL, Gabriel CS, Fertonani HP, Matsuda LM. Management changes resulting from hospital accreditation. Rev Lat Am Enfermaqem 2017;25:e2851. DOI: 10.1590/1518-8345.1394.2851

6. Joint Commission International. JCI-accredited organizations. Available at http://www.jointcommissioninternational.org/about-jci/jci-accredited-organizations [accessed on March 03, 2021].

7. Joint Commission International. Joint Commission International Accreditation Standards for Hospitals. Available at http://www.jointcommissioninternational.org/assets/3/7/JCI-Hospital-5E-Standards-OnlyJuly2015.pdf/ [accessed on August 03, 2017].

8. Joint Commission International. Joint Commission International Accreditation Standards for Ambulatory Care. Available at http://www. jointcommissioninternational.org/assets/3/7/JCI_Ambulatory_Care_ 3e_STANDARDS_ONLY.pdf/ [accessed on August 25, 2017].

9. AllforSkin Dermatology Clinic, Hair \& Laser Center in Daegu Acquired a JCI Accreditation. Available at https://www.jointcommissioninternational.org/about-jci/accredited-organizations/\#q=South\%20Korea [accessed on March 02, 2021].

10. Cousins DD, Heath WM. The National Coordinating Council for Medication Error Reporting and Prevention: promoting patient safety and quality through innovation and leadership. Jt Comm J Qual Patient Saf 2008;34(12):700-702. DOI: 10.1016/s1553-7250(08)34091-4 


\section{국문초록}

\section{소규모 의원의 Joint Commission International 인증: 사례보고}

\section{황연수 ${ }^{1} \cdot$ 이혜원 $·$ 김은희 ${ }^{3} \cdot$ 민복기 ${ }^{4}$}

1경북대학교 간호대학 학생, ${ }^{2}$ 경북대학교병원 임상약리학과 \& 임상시험센터 임상교수, ${ }^{3}$ 대구가톨릭대학교 간호대학 교수, ${ }^{4}$ 올포스킨피부과의원 원장

목적: 환자의 안전과 의료의 질에 대한 관심이 증가함에 따라 병원 인증이 세계적으로 증가하고 있다. 국제의료기관평가위원회(Joint Commission International, JCI) 인증이 가장 대표적인 병원 국제인증이다. JCI 인증기준에 속하는 광범위한 척도들은 실제적으로 큰 기 관들에게 더 유리하다. 그러나, 소규모 의원의 역량에 적합한 JCI 체계를 구축하는 것이 가능하다. 이 사례 보고는 소규모 의원에서의 인 증 관련 업무 경험을 요약하고, JCI 인증 전후 기간 동안 외래 환자 진료시에 이러한 인증에서 얻은 교훈을 논의하고자 하였다.

방법: 2016년에 성공적으로 JCI 인증을 받은 한 소규모 의원을 3년 동안 관찰하였다. JCI 인증 업무를 담당한 직원과의 면담을 통하여 자료를 수집하였다. JCI 인증 전후 기간 동안 외래 환자 진료시에 이러한 인증에서 얻은 교훈과 함께, 국제 환자 안전 목표 및 투약관리 에 집중하여 연관 경험을 요약하였다.

결과: 인증을 위한 업무과정에 참여하고 3 년 동안 후속 관찰한 결과, 이 의원의 환자의 안전 및 의료의 질 개선을 위한 기준 만족 수준 이 초기에는 낮았고, 이후 유의하게 개선되었다.

결론: 결론적으로, 이 사례 보고에 따르면, 소규모 의원에서의 JCI 인증으로 관심과 역량이 고취되어 의료의 질을 성공적으로 개선하 였다.

주제어: JCI, 소규모 의원, 인증, 질 향상, 약물관리 